\title{
Sürdürülebilir Kalkınma İçin Yenilenebilir Enerji Kaynaklarının Türkiye Ölçeğinde Değerlendirilmesi
}

\author{
Cem Emeksiz ${ }^{1 *}$, Muhammed Musa Findık ${ }^{2}$ \\ 1* Tokat Gaziosmanpaşa Üniversitesi, Mühendislik ve Mimarlık Fakültesi, Elektrik-Elektronik Mühendisliği Bölümü, Tokat, Türkiye, \\ (ORCID: 0000-0002-4817-9607), cem.emeksiz@gop.edu.tr \\ 2 Tokat Gaziosmanpaşa Üniversitesi, Mühendislik ve Mimarlık Fakültesi, Elektrik-Elektronik Mühendisliği Bölümü, Tokat, Türkiye, \\ (ORCID: 0000-0003-3786-6089), fmuhammedmusa@gmail.com.
}

(3rd International Congress on Human-Computer Interaction, Optimization and Robotic Applications June 11-13, 2021)

(DOI: 10.31590 /ejosat.948729)

ATIF/REFERENCE: Emeksiz, C. \& Fındık, M.M., (2021). Sürdürülebilir Kalkınma İçin Yenilenebilir Enerji Kaynaklarının Türkiye Ölçeğinde Değerlendirilmesi. Avrupa Bilim ve Teknoloji Dergisi, (26), 155-164.

Öz

Dünya üzerinde enerji kaynaklarına duyulan ihtiyaç gün geçtikçe artarak büyümektedir. Gelişmekte olan ülkelerde nüfus giderek artmakta, toplumların yaşam standartları gün geçtikçe yükselmekte ve sanayileşme faaliyetleri yaygınlaşmaktadır. Teknolojik anlamda ilerleme ile paralel olarak enerjiye duyulan ihtiyacın artması ve önümüzdeki yıllarda daha da artacak olması kaçınılmaz bir gerçektir. Fosil yakıtlar olarak adlandırılan doğal enerji kaynakları geçmişten günümüze yaygın olarak enerjiye duyulan ihtiyacın karşılanması adına yıllardır kullanılmaktadır. Bu fosil yakıtların dünya üzerinde önemli derecede çevresel problemlere neden olması ve yakın tarihte rezervlerinin bitecek olması önemli bir sorun teşkil etmektedir. Enerji temini ve tedarikinin sağlanmasında fosil yakıtlara bağlı kaynakların kullanımı için en önemli alternatif yenilenebilir enerji kaynaklarıdır. Türkiye, yenilenebilir enerjiye olan ilginin arttığı bu dönemde gerek özel sektör gerekse devlet kanallı teşvikler ile önemli yatırımlar yapmaktadır. Yenilenebilir enerji kaynakları bakımından da oldukça zengin bir altyapıya ve hammaddeye sahiptir. Bu çalışmada Türkiye'nin mevcut enerji potansiyeli incelenerek, yenilenebilir enerji alanındaki son gelişmeler, yatırımları ve son durumu değerlendirilmiştir.

Anahtar Kelimeler: Yenilenebilir enerji kaynakları, Fosil yakıtlar, Enerji politikası, Türkiye.

\section{Evaluation of Renewable Energy Resources for Sustainable Development in Turkey}

\begin{abstract}
The need for energy resources on earth is growing day by day. In developing countries, the population and the living standards of societies are increasing day by day, and industrialization activities are becoming widespread. It is an inevitable fact that the need for energy will increase in parallel with technological progress and will increase even more in the coming years. Natural energy sources, called fossil fuels, have been widely used for years to meet the need for energy from the past to the present. The fact that these fossil fuels cause significant environmental problems around the world and have run out of reserves in recent history poses a significant problem. Renewable energy sources are the most important alternative for the use of fossil fuel-dependent resources in the supply and providement of energy. During this period, when interest in renewable energy is growing, Turkey makes significant investments with incentives through both the private sector and the state channel. It has a very rich infrastructure and raw materials in terms of similar renewable energy sources. In this study, Turkey's current energy potential was examined and recent developments, investments and recent status in the field of renewable energy were evaluated.
\end{abstract}

Keywords: Renewable energy sources, Fossil fuels, Energy policy, Turkey.

*Sorumlu Yazar: cem.emeksiz@gop.edu.tr 


\section{Giriş}

Sosyal ve ekonomik sürdürülebilirlik bakımından enerji kaynakları yaşamımızda oldukça önemli bir yere sahiptir. Endüstri Devriminin beraberinde getirdikleri bireylerin enerji kaynaklarına olan ilgisini ve talebini arttırmıştır. $\mathrm{Bu}$ artış günümüzde ve gelecekte hızla büyüyerek devam etmektedir (Y1lmaz, 2012).

Uluslararası Enerji Ajansı'nın yapmış olduğu araștırmalara bakıldığında dünya birincil enerji talebi 14 milyar ton eşdeğer petrol (TEP) olarak hesaplanmıştır. Bu durumdaki enerji tüketim hızı ve aynı zamanda mevcut politikalar devam edecek olursa önümüzdeki 20 y1l gibi bir süreçte \%45'lik bir artış ile 20,3 Milyar TEP seviyesine ulaşabilecektir. Çin en fazla enerji tüketen ülkeler arasında birinci sırada yerini almaktadır. Türkiye 129,3 milyon ton eşdeğer petrol birincil enerji tüketimi ile 2015 yılında listede 19.sırada yer almaktadır (Türkiye Doğalgaz Dağıtıcıları Birliği, 2016). 2020 yılı itibariyle Türkiye en fazla enerji tüketen ülkeler arasında 17. sırada yer alarak iki basamak yükselmiştir (Worldometer, 2020).

İçerisinde bulunduğumuz asırda, evrenimizin karşı karşıya kaldığ1 önemli problemlerin başında enerjinin güvenli ve sürdürülebilir tedariki gelmektedir. Refah seviyelerine bakıldığında özellikle gelişmiş denebilecek seviyedeki dünya ülkelerinde enerji üretimi ve kullanımı devam ettirilebilir bir yapıya sahip değildir. $\mathrm{Bu}$ durumun sebepleri arasında, enerji ihtiyacının dünya genelinde \%80-90 gibi büyük bir yüzde ile fosil temelli yakıtlar aracılığıla elde edilmesinden kaynaklanmaktadır. Endüstrinin getirdiği sanayileşme ve nüfusun artmasından kaynaklanan enerjiye olan ihtiyacı evrenimizin mevcut sınırlı kaynaklarıyla giderilememekte, mevcut enerji üretiminin ihtiyaç duyulan tüketimi karşılayamadığ görülmektedir. Bir diğer yandan, doğal enerji kaynakları (fosil yakıtlar) enerji üretimi bakımından çevre kirliliğine yol açmakta ve günümüzün önemli sorunlarından olan iklim değişikliğinin nedenleri arasında yer almaktadır. Aynı zamanda, fosil yakıtlarının miadının dolacağı ve tükeneceği bir gerçektir. Çeşitli endüstriyel çalışmalar neticesinde her y1l gezegenimizin atmosferine yaklaşık olarak 2 milyon ton kurşun, 100 milyon ton kükürt bileşikleri, 20 milyar ton karbondioksit ayrıca farklı zararlı kimyasal bileşiklerin salınımı gerçekleşmektedir (Kadıoğlu ve Tellioğlu, 1996).

Türkiye jeotermal, rüzgar, biyokütle, güneş, deniz-okyanus, hidrolik enerji gibi yenilenebilir kaynaklar bakımından oldukça zengin bir altyapıya sahip olmasına rağmen, mevcut potansiyelini yeterince kullanamamaktadır. Resmi kuruluşlara göre fosil yakıta duyulan ihtiyacı daha da çoğaltacak ve dışa bağımlılığı artıracak enerji ithaline neden olacak ihale planları mevcuttur (Kumbur ve ark., 2005).

Enerji tedarikinde ve temininde fosil temelli kaynak kullanımı için en büyük alternatif yol yenilenebilir ve sürdürülebilir enerji kaynaklarına ilginin artarak büyümesini sağlamaktır. Yenilenebilir enerji kaynaklarının doğaya zarar vermemesinin yanı sıra rağbet görmesini sağlayan önemli etkenler sırasıyla; ülke olarak dışa bağımlılığın asgari seviyelere indirilmesi, yenilenebilir enerji tesislerinin kurulum maliyeti ve üretilen enerjinin getirdiği gelir ile kıyaslandığında çok ucuz enerji sağlamaları ve yüksek miktarlarda yakıt giderlerinin olmamasıdır. $\mathrm{Bu}$ çeşitli artıları nedeniyle her geçen gün yenilenebilir enerji kaynaklarına olan ilgi ve talep ciddi olarak artmaktadır (Atç1, 2012). Enerji ve çevre faktörünü bir arada değerlendirerek enerji politikalarının belirlenmesi gerekmektedir. Gelişmiş ülkelerin birçoğu doğa dostu olan yenilenebilir enerji kaynaklarından faydalanmaya son derece önem vermektedir. Gelecek yıllar bu bakımından, temiz ve tükenmez enerji kaynaklarının yaygınlaşmasında önemli gelişmelerin yaşanacağ 1 bir gelecek olma görüntüsü vermektedir. Değerlendirmeler sonucunda yenilenebilir enerji kaynaklarından güneş, rüzgar, biyokütle ve hidroelektrik enerjisi bakımından Türkiye'nin büyük bir potansiyele sahip olduğu görülmektedir. Türkiye, kurulu güç açısından yenilenebilir enerjide Dünya'da 12. ve Avrupa'da 5. sıraya yükselerek yerleşmiştir. 2021 başı itibariyle Türkiye'de kurulu gücün \%52'si yenilenebilir kaynaklardan meydana gelmektedir (Türkiye Cumhuriyeti Dışişleri Bakanlığı, 2021). Türkiye'de bu gibi yenilenebilir enerji kaynakları hem devlet hem de özel sektör tarafindan büyük bir yatırım almaktadır. Burada esas olan, Türkiye'de mevcut yenilenebilir enerji kaynakları, potansiyelleri, politik açıdan bu alana yapılan yatırımlar ve Türkiye açısından bu kaynakların ne kadar önemli olduğu noktasında mevcut farkındalığı daha üst seviyelere çıkarmaktır. $\mathrm{Bu}$ çalışmada yenilenebilir enerji kaynakları incelenerek Türkiye'deki potansiyelleri ve yatırım durumları hakkında bilgiler içeren bir araştırma gerçekleştirildi.

\section{Enerji Kaynakları}

Günümüzde büyük öneme sahip olan enerjiyi kısaca tanımlayacak olursak; iş yaptırabilen güç olarak ifade etmemiz mümkündür. Enerjinin üretimi için kullanılan kaynaklar enerji kaynakları olarak isimlendirilir. Enerji kaynakları, doğal enerji kaynakları ve yenilenebilir enerji kaynakları olmak üzere ikiye ayrılmaktadır. Enerji kaynaklarından elektrik enerjisinin üretimi ihtiyaç duyulan enerji ihtiyacının karşılanabilmesi adına son derece önemlidir. Türkiye'de enerji kaynaklarından faydalanarak elektrik enerjisi üreten ülkeler arasında yer almaktadır. Türkiye'deki elektrik tesislerine kurulu güç olarak bakıldığında Mart 2021 verilerine göre toplam kapasitenin 97069,7 MW'llk olduğu görülmektedir (Türkiye Elektrik İletim A.Ş., 2021). Tablo 1 incelendiğinde Türkiye'deki birincil kaynaklara göre santral sayısı ve kurulu güçleri detaylı olarak görülmektedir. Santral adeti bakımından güneş enerjisinden yararlanılan santral sayısı ilk sırada yer almaktadır. Kurulu güç açısından incelendiğinde ise doğalgaz ile çalışan santraller başı çekmektedir. Ayrıca Türkiye'deki birincil kaynaklara göre kurulu gücü temsil eden dağglım grafiği Şekil 1'de verilmektedir.

Tablo 1. Kaynaklara göre santral sayısı ve kurulu güçleri

\begin{tabular}{|c|c|c|}
\hline $\begin{array}{l}\text { BÍRINCIL } \\
\text { KAYNAK }\end{array}$ & $\begin{array}{c}\text { SANTRAL } \\
\text { SAYISI }\end{array}$ & $\begin{array}{c}\begin{array}{c}\text { KURULU GÜÇ } \\
(\mathrm{MW})\end{array} \\
\end{array}$ \\
\hline$A K A R S U$ & 579 & 8090,4 \\
\hline $\begin{array}{l}\text { ASFALTIT } \\
\text { KÖMÜR }\end{array}$ & 1 & 405 \\
\hline ATIK ISI & 85 & 366,2 \\
\hline BARAJLI & 133 & 23236,6 \\
\hline BIYYOKÜTLE & 275 & 1147,9 \\
\hline$D O \breve{G} A L G A Z$ & 342 & 25697,8 \\
\hline FUEL OIL & 9 & 251,9 \\
\hline$G \ddot{U N E S ̧}$ & 7779 & 6964 \\
\hline
\end{tabular}




\begin{tabular}{l|c|c}
\hline ITHAL KÖMÜR & 15 & 8986,9 \\
\hline JEOTERMAL & 60 & 1623,9 \\
\hline LINYİT & 47 & 10119,9 \\
\hline LNG & 1 & 2 \\
\hline MOTORIN & 1 & 1 \\
\hline NAFTA & 1 & 4,7 \\
\hline RÜZGAR & 333 & 9360,6 \\
\hline TAŞKÖMÜR & 4 & 810,8 \\
\hline TOPLAM & 9665 & 97069,7 \\
\hline
\end{tabular}

kaynağı olarak sanayi tesislerinde kullanılmaktadır. Doğal gaz bakımından Türkiye kısıtllı rezervlere sahiptir. Tespit edilebilmiş olan rezervin Türkiye'deki miktarı 17,5 milyar $\mathrm{m}^{3}$ doğal gazdır (Kumbur ve ark., 2005).

Enerjide önemli bir yere sahip olan petrol, Dünya'daki toplam enerji tüketiminin $\% 45^{\prime}$ lik bir payına sahiptir. Türkiye'de \%44'lük bir enerji tüketimine sahip olan petrol mevcut kaynaklar arasinda önemli bir konuma sahiptir (Kumbur ve ark., 2005). 340.863 metre sondaj çalışması sonucunda 2019 yılında Türkiye'de 153 petrol kuyusu hizmete alınmıştır. 2.984.800 ton ham petrol olarak üretimi gerçekleşmiş olup kalan 51.076.078 ton üretilebilir petrol rezervi mevcuttur (Türkiye Cumhuriyeti Enerji ve Tabii Kaynaklar Bakanlığı, 2021).

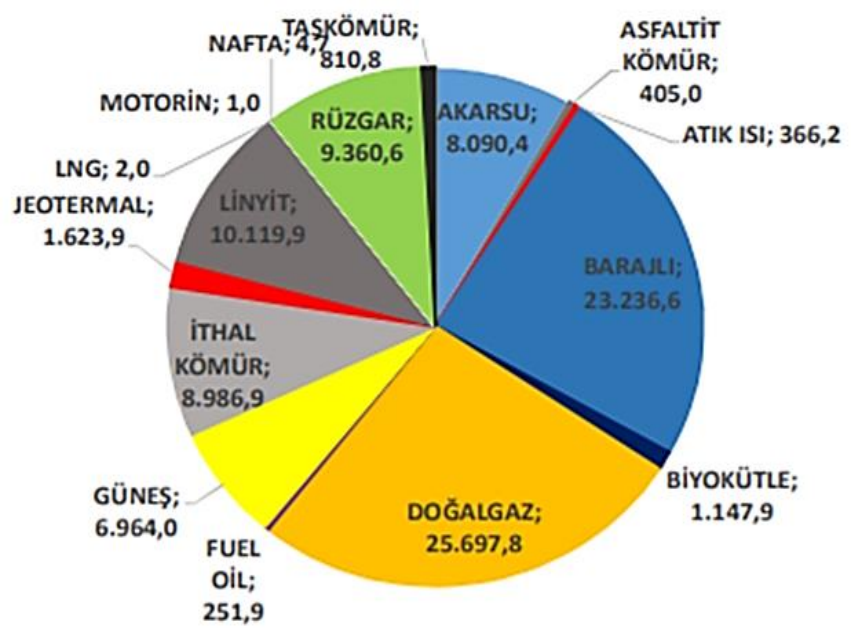

Atomun parçalanması ile elde edilen ve hızla rezervleri bitmekte olan petrole karşı farklı bir seçenek olarak gösterilen nükleer enerji günümüzde üzerinde çalışmalar yapılan önemli bir enerji türüdür (Kadığlu ve Tellioğlu, 1996). Türkiye'de de nükleer santral kurulması çalışmaları Mersin Akkuyu Nükleer Güç Santrali ile devam etmektedir. Çalışmalar tamamlandığında Türkiye Cumhuriyeti Devleti ilk nükleer enerji santraline sahip olacaktır.

\subsection{Yenilenebilir Enerji Kaynakları}

Ülkeler yenilenebilir enerji kaynakları bakımından değerlendirilecek olursa biyokütle, güneş, rüzgar, jeotermal, deniz-okyanus ve hidrolik enerji gibi kaynaklardan faydalanmaktadır.

Samanyolu Galaksi'sinde Güneş, son derece önemli bir yere sahiptir. Dünya için vazgeçilmez bir yaşam kaynağı olup aynı zamanda yenilenebilir enerji kaynakları arasında kendi içinde önemli derecede enerji potansiyeli barındıran bir enerji kaynağıdır. Genel bir bakış açısıyla gözlemlendiğinde enerji kaynakları arasında güneş birincil enerji kaynağıdır (Acaroğlu, 2003). Güneş enerjisi, güneşin merkezinde yer bulan füzyon (helyuma dönüşen hidrojen gazının) tepkimesi ile beraberinde ışıma enerjisi ortaya çıkmaktadır. Güneş enerjisinin şiddeti Dünya'nın atmosferinin dışarı kısmında, yaklaşık olarak 1370 $\mathrm{W} / \mathrm{m}^{2}$ seviyesindedir, fakat yerküreye ulaşabilen miktar 0-1100 $\mathrm{W} / \mathrm{m}^{2}$ şiddeti değeri arasındadır ve bu denli güneş enerjisinin şiddetinin azalmasının nedeni atmosferde güneş fotonlarının absorbe edilmesinden kaynaklanmaktadır ( Türkiye Cumhuriyeti Enerji ve Tabii Kaynaklar Bakanlığı, 2021).

Rüzgar Enerjisi; ana kaynağı güneş olan bir enerji çeşididir. Yakın konumdaki bölgelerin birbirine olan sınırı ile aralarında basınç farkları oluşan ve bu potansiyel farktan dolayı meydana gelen hava akımı olayına rüzgar denir (Gökkuş, 2014). Rüzgar, hava akımının daha yüksek basınç merkezinden daha alçak basınç merkezine doğru hareketini gerçekleştirmesi olayıdır (Yapar, 2014). Rüzgar yön ve hız olarak iki farklı değişken ile tanımlanmaktadır. Rüzgarın teorik gücü, hızının küpü ile orantılı olarak değişmektedir ve aynı zamanda artan yükseklikle rüzgar hızı artmaktadır (Türkiye Cumhuriyeti Enerji ve Tabii Kaynaklar Bakanlığı, 2021). Elektrik üretiminin rüzgar enerjisi kaynağından yararlanılarak gerçekleştirilmesinde karşılaşılan problerin başında üretim tesislerinde yatırımının bütçe ekonomisi açısından fazla olması, yeterince yüksek olmayan kapasite etkenlerinin ve değişkenlik gösteren enerji üretimi gelmektedir. Bunun yanı sıra temiz ve yenilenebilir bir enerji kaynağıdır, doğa dostudur, işletme ve bakım masraflarının düşük olması, işletmeye alınması kısa sürelerde gerçekleşiyor olması gibi birden fazla artısı vardır. 
Yeryüzünün farklı derinliklerinde geçmişten günümüze biriken ısının ve basıncın oluşturduğu sıcaklıkları atmosferik ısının üstünde olan gaz, buhar ve sicak su olarak ifade edilen jeotermal enerji, kapsamlı olarak incelendiğinde doğaya verebileceği zarar açısından temiz bir enerji kaynağı olarak kabul görmektedir (Kumbur ve ark., 2005). Doğal kaynaklar kullanılmaktadır ve bu nedenle dışa olan bağımlılığı çok azdır. Jeotermal sahalarda açılmış olan kuyulardan elde edilen akışkan seperatörlerde su ve buhar olarak ayrıştırma işleminin ardından türbin ve jeneratör vasıtasıyla elektrik enerjisi üretilir (Türkiye Cumhuriyeti Enerji ve Tabii Kaynaklar Bakanlığı, 2021).

Organik bir karbon olarak kabul gören biyokütle 100 yıllık bir süreçten daha kısa zamanda kendini yenileyebilen, suda ve karada yetişen bitkiler, hayvan artıkları, orman ürünleri ve besin endüstrisi ile çeşitli kentsel atıkları içerisinde barındıran tüm organik maddeler bütünü olarak ifade edilir (Kumbur ve ark., 2005).

Deniz-Okyanus enerjisi; sıcaklık gradyent enerjisi, tuzluluk gradyent enerjisi, gel-git (med-cezir) enerjisi, akıntı enerjisi, dalga enerjisi ve yüzey buharlaşma enerjisi olarak sıralanmaktadır (Kumbur ve ark., 2005). Deniz-Okyanus enerjisinin temelinde yine rüzgar enerjisi vardır. Günümüz ekonomik ve teknik özellikleri ele alındığında; gel-git ve dalga harici deniz enerjilerin türlerinden enerji elde edilmesi günümüz koşullarında mümkün değildir (Mert, 2012). Ekonomik ve teknik sebeplerden dolayı, deniz- okyanus enerjileri içerisinde genel olarak kendisine uygulama alanı bulan enerji türleri dalga ve gel-git enerjisidir.

Yenilenebilir enerji kaynakları arasında insanın ilk asırlardan bu zamana kadar en çok tercih edilen ve yaygın olarak kullandığ enerji kaynağı hidrolik enerjidir. Güneş kaynaklı bir enerji türü olan hidrolik enerji suyun çevrimi enerjisinden meydana gelmektedir. Yerküre de bulunan deniz, nehir ya da göl gibi su kütleleri, güneşin bu su kütlelerini ısıtması ile buharlaşmaktadır. Rüzgarın sürüklemesiyle su buharları harekete geçmekte ve atmosfer şartlarına göre yoğunlaşarak yağmur ya da kar benzeri yağışları meydana getirmektedir. Akarsuların beslenmesi adına bu yağışlar önemli katkı sağlamaktadır. Hareket etmekte olan su kütlesi hidrolik enerjiyi meydana getirmektedir. Bu sistemde su kütlesinin taşımakta olduğu enerji devamlı olarak kendisini yineleyen bir enerji türüdür. Enerji kaynakları arasında hidrolik enerji elektrik üretiminde ön plandadır. Hidroelektrik enerji; su kütlesinin akım enerjisinden yararlanılarak kanal veya cebri boru vasıtasıyla yerden yüksekliği olan bir noktadan türbine iletilir ve mekanik enerjiye dönüştürülür. Tahrik edilen türbinlerin jeneratörleri döndürmesi ile elektrik enerjisi üretimi gerçekleşmektedir (Tekno Tasarım, 2021). Düşük potansiyel risk taşımaları ve çevre dostu olmaları nedeniyle hidroelektrik enerji santrallerine yaygın olarak tesisleşme açısından yatırımlar yapılmaktadır. Hidroelektrik santraller; yenilenebilir, yakıt gideri olmayan, temiz, çevreye uyumlu, yüksek verimli, işletme gideri çok düşük uzun ömürlü ve devletler açısından başka ülkelere bağımlı olma durumunun söz konusu olmadığ enerji kaynağıdır (Türkiye Cumhuriyeti Enerji ve Tabii Kaynaklar Bakanlığ1, 2021).

\section{Türkiye'de Yenilenebilir Enerji Kaynaklarının Potansiyeli ve Politikaları}

Türkiye ölçeğinde yenilenebilir enerji kaynakları incelenecek olursa; güneş, rüzgar, jeotermal, biyokütle ve hidrolik enerji gibi kaynaklardan büyük oranda yararlanıldığı görülmektedir.

Güneş potansiyeli bakımından Türkiye sayılı ülkeler arasında yerini almaktadır. Şekil 2'de Türkiye'nin ortalama güneşlenme süresi görülmektedir. 1988-2017 yılları arasında yapılan çalışmalarda Meteoroloji Genel Müdürlüğü (MGM) istasyonlarında ölçülen günlük verilerden hesaplanan uzun yıllar ortalamaları ile güneşlenme süresi olarak kayıt altına alınan istatistikler ile elde edilmiştir. Uzun yıllardır MGM çatısı altında helyograf cihazı ile yapılmakta olan güneşlenme süresi ölçüm değerleri, 21. yüzyılın başından itibaren Otomatik Meteoroloji Gözlem İstasyonlarına (OMGI) kurularak ayarlanan güneşlenme süresi ölçer cihazlar ile ölçümlere devam edilmektedir. 1988-2017 seneleri arasında toplam günlük güneşlenme süreleri dikkate alındığında, Türkiye için hesaplanan 6,37 saat ile en düşük yıllık ortalama güneşlenme süresi 1988 yılında, 7,30 saat ile en yüksek güneşlenme süresi ise 1990 yılında kayıtlara geçmiştir (Türkiye Cumhuriyeti Meteoroloji Genel Müdürlüğü, 2018).

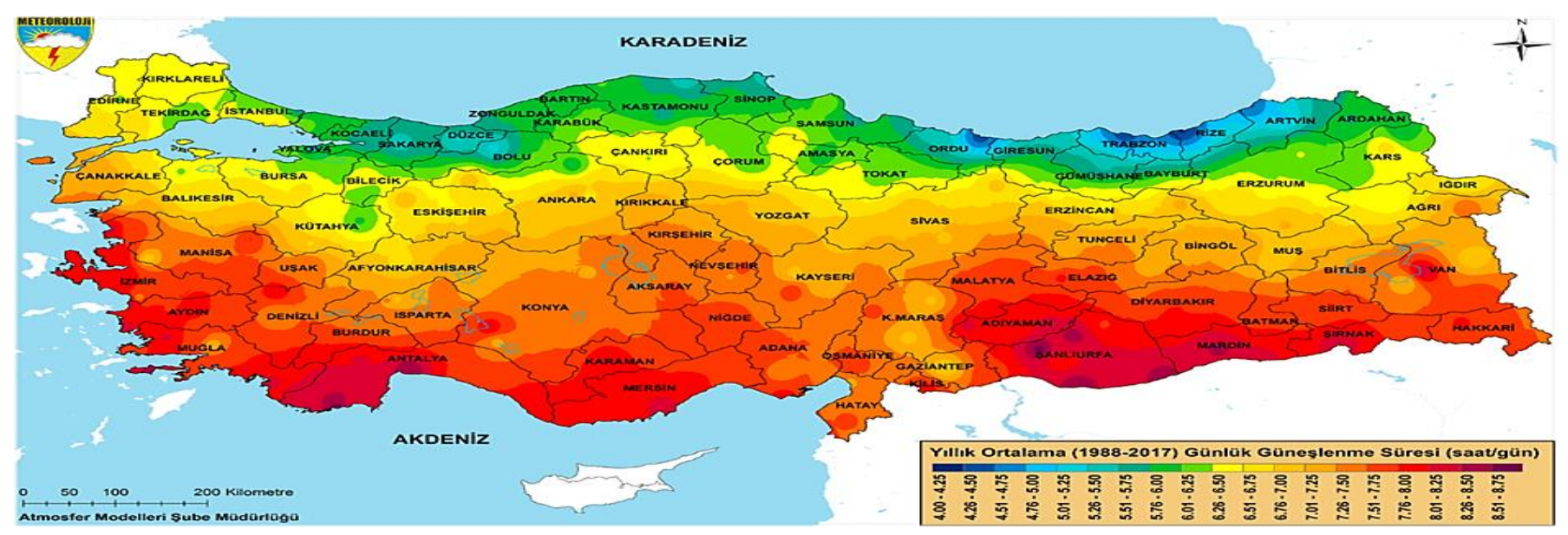

Şekil 2. Türkiye'nin ortalama güneşlenme süresi

Türkiye Güneş Enerjisi Potansiyeli Atlası, Türkiye Cumhuriyeti Enerji ve Tabii Kaynaklar Bakanlığ tarafindan hazırlamış olup, bu atlasa göre elde edilen yıllık ve günlük veriler Tablo 2'de görülmektedir. Tablo 2 incelendiğinde Türkiye genelinde ortalama günlük güneşlenme süresi ve olarak, ortalama toplam ışınım şiddeti sırasıyla 7,5 saat/gün ve $4,18 \mathrm{kWh} / \mathrm{m}^{2}$-gün olarak hesaplanmıştır. Son yıllarda güneş enerjisinden farklı alanlarda ve biçimlerde faydalanılmasıyla beraber elektrik 
enerjisi üretiminde genellikle tercih edilen iki teknoloji yöntemi mevcuttur. Bunlardan birincisi; güneş hücreleri de denilen ve yarı iletken malzemelerden meydana gelen, güneşten gelen 1şınları elektrik enerjisine doğrudan dönüştüren panellerdir. İkincisi ise odaklanmış güneş enerjisi (csp) ve isıl güneş teknolojileridir. Güneş enerjisinden asıl olarak üretilen enerji ısı enerjisidir. Isıdan doğrudan faydalanılacağı gibi elektrik üretiminde de kullanılabilir (Enerji ve Tabii Kaynaklar Bakanlığı, 2021).

Tablo 2. Türkiye güneş enerjisi potansiyeli atlasına göre elde edilen ylllk ve günlük veriler

\begin{tabular}{l|c}
\hline $\begin{array}{l}\text { Ortalama yıllık olarak toplam güneşlenme } \\
\text { süresi }\end{array}$ & 2741,07 saat/yıl \\
\hline $\begin{array}{l}\text { Ortalama günlük olarak toplam güneşlenme } \\
\text { süresi }\end{array}$ & $7,50 \mathrm{saat} / \mathrm{gün}$ \\
\hline $\begin{array}{l}\text { Ortalama yıllık olarak toplam ışınım şiddeti } \\
\mathrm{kWh} / \mathrm{m}^{2}-\mathrm{y} 1 \mathrm{l}\end{array}$ \\
\hline $\begin{array}{l}\text { Ortalama günlük olarak toplam ışınım } \\
\text { şiddeti }\end{array}$ & $\begin{array}{c}4,18 \mathrm{kWh} / \mathrm{m}^{2}- \\
\mathrm{gün}\end{array}$ \\
\hline
\end{tabular}

Türkiye'de güneş enerjisi potansiyeli bölgelere göre dağılımı Tablo 3'de görülmektedir (Koç ve Şenel, 2013). Tablo 3 incelenecek olursa en fazla potansiyele sahip bölge Güneydoğu Anadolu Bölgesi, en az seviyede potansiyele sahip bölge ise Karadeniz Bölgesi olarak görülmektedir.

Türkiye Mart 2021 itibariyle 7779 adet güneş enerjisi santrali ve 6964 MW kurulu güce ulaşmıştır (Türkiye Elektrik İletim A.Ş., 2021). Gelecekte yapılacak yatırımlar için güneş enerjisi santral sayısı ve kurulu gücün arttırılmasına yönelik devlet tarafından çeşitli teşviklerin ve kanunların düzenlendiği bilinmektedir. 18/5/2005 tarihli 5346 sayılı Yenilenebilir Enerji Kaynaklarının Elektrik Enerjisi Üretimi Amaçlı Kullanımına İlişkin Kanun ile "Bu kaynakların elektrik enerjisi üretimi amacı ile kullanılmasının yaygınlaştırılması, bu gibi kaynakların ekonomik, kaliteli ve güvenilir olarak ekonomiye kazandırılması, kaynakların çeşitlendirilmesi, sera gazı emisyonlarının asgari seviyelere indirilmesi, çeşitli atıkların kullanılması, doğanın korunması ve bu amaçların uygulanabilmesine ihtiyaç duyulan üretim sektörünün geliştirilmesi adına destek sağlamaktadır" (Resmi Gazete, 2005).

Tablo 3. Türkiye'de güneş enerjisi potansiyelinin bölgelere göre dağılımı

\begin{tabular}{l|c|c}
\hline Bölge & $\begin{array}{c}\text { Toplam Güneş } \\
\text { Enerjisi kWh/m²- } \\
\text { yıl }\end{array}$ & $\begin{array}{c}\text { Güneşlenme } \\
\text { süresi (Saat/yıl) }\end{array}$ \\
\hline Karadeniz & 1120 & 1971 \\
\hline Marmara & 1168 & 2409 \\
\hline Ege & 1304 & 2738 \\
\hline Iç Anadolu & 1314 & 2628 \\
\hline Doğu Anadolu & 1365 & 2664 \\
\hline Akdeniz & 1390 & 2956 \\
\hline Güneydoğu Anadolu & 1460 & 2993 \\
\hline
\end{tabular}

Rüzgar enerjisi kapasitesinde kurulu güç açısından Türkiye dünya genelinde ilk sıralarda yer almamasına karşın rüzgar enerjinin potansiyel bakımından çok daha ön sıralarda bulunmaktadır. Karşılaştırılma yapılacak olursa potansiyeli bakımından Türkiye, diğer Avrupa ülkelerine kıyaslandığında başı çeken ülkeler arasında kendisine yer bulmaktadır. Rüzgar enerjisi potansiyeli açısından Türkiye; yüksekliği 50 m'de 7,5 $\mathrm{m} / \mathrm{s}$ 'den daha yüksek hızdaki rüzgarın var olduğu bölgeler incelendiğinde elektrik enerjisi üretimi potansiyeli için kayıtlara geçen değer yaklaşık 48 bin MW olarak hesaplanmaktadır (Bektaş, 2013). 50 metre yükseklikte Türkiye bölgesinin geneline bakıldığında yıllık hesaplamalara göre ortalama rüzgar hızları dağılımı haritası Şekil 2'de görüldüğü gibidir (Çalışkan, 2019).

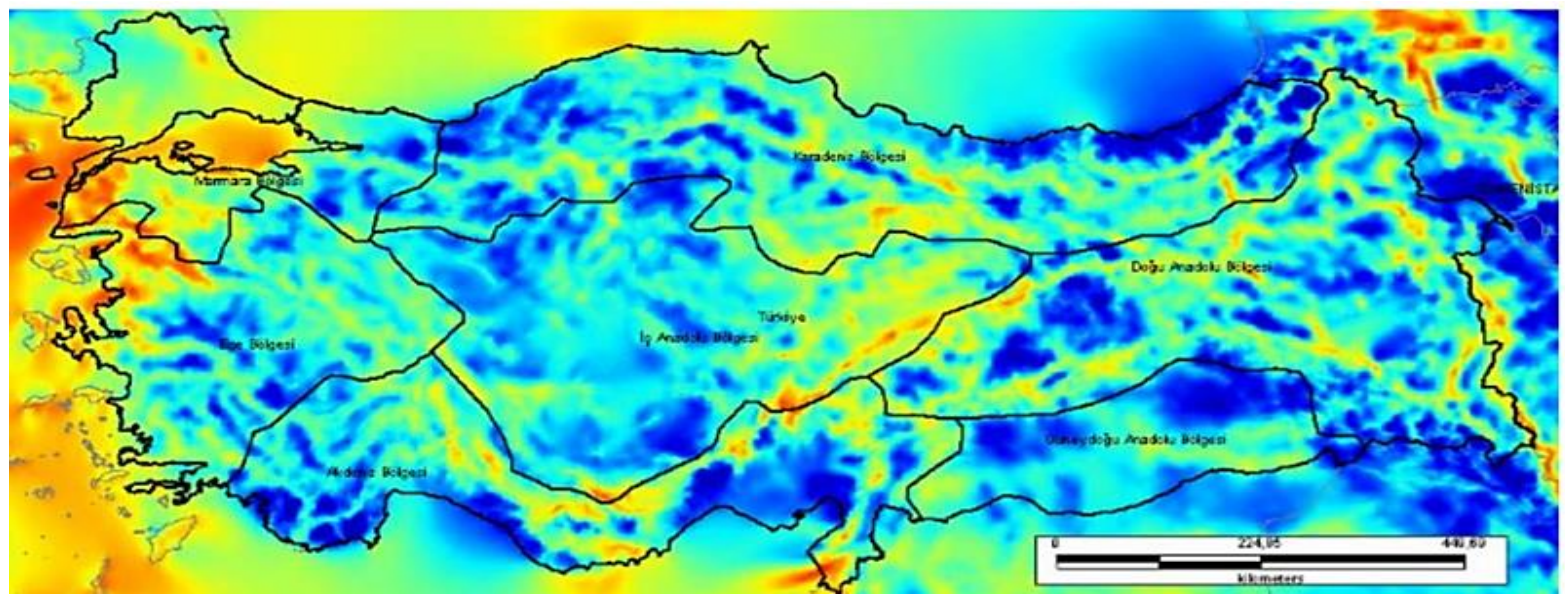

RÜZGAR HIZI

Şekil 3. Türkiye'de 50 metre yükseklikteki ortalama yıllık rüzgar hızları dağılımı

Türkiye genelinde 50 metre yükseklikte güç yoğunluğunun ortalaması dağılımı haritası Şekil 4'de görüldüğü gibidir
(Çalışkan, 2019). Özellikle Ege kıyılarında ortalama güç yoğunluğunun Şekil 4'e bakıldığında fazla olduğu görülmektedir. 


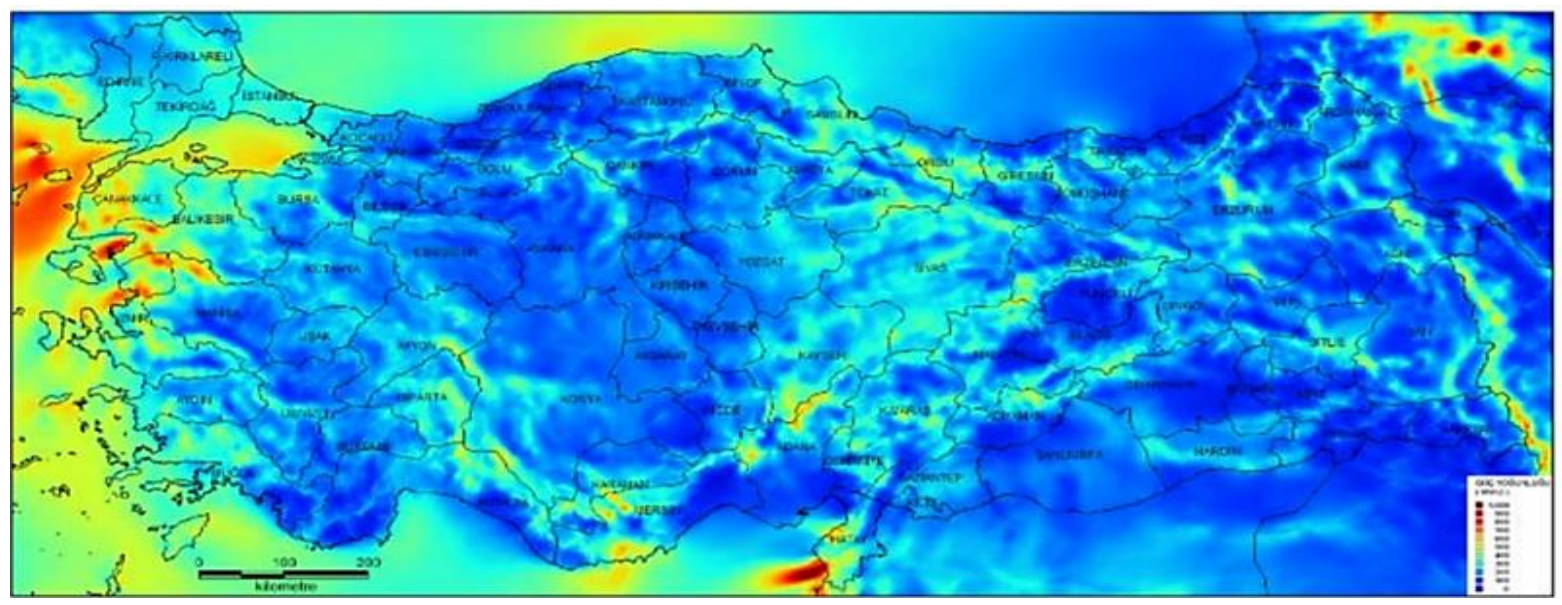

\section{GÖç YOǦUNLUĞU $\left(W / m^{2}\right)$}

Şekil 4. Türkiye için 50 metre yükseklikteki ortalama güç yoğunluğu dă̆glımı

50 metre yükseklikte Türkiye geneli kapasite faktörü dağılımının ortalama değeri Şekil 5'de görüldüğü gibidir (Çalışkan, 2019). Ölçülen değerlerde $1 \mathrm{MW}$ gücündeki rüzgar türbinine ait teknik veriler referans olarak kabul edilmiştir. Mali açıdan rüzgar enerjisi santrali yatırımlarının ekonomik getirisinin olabilmesi adına yaklaşık olarak \%35 veya daha yüksek değerlerde kapasite faktörüne ihtiyaç duyulmaktadır. Bu durum göz önüne alındığında kıyı bölgeler kapasite faktörü açısından daha avantajlı konumda yer almaktadır.

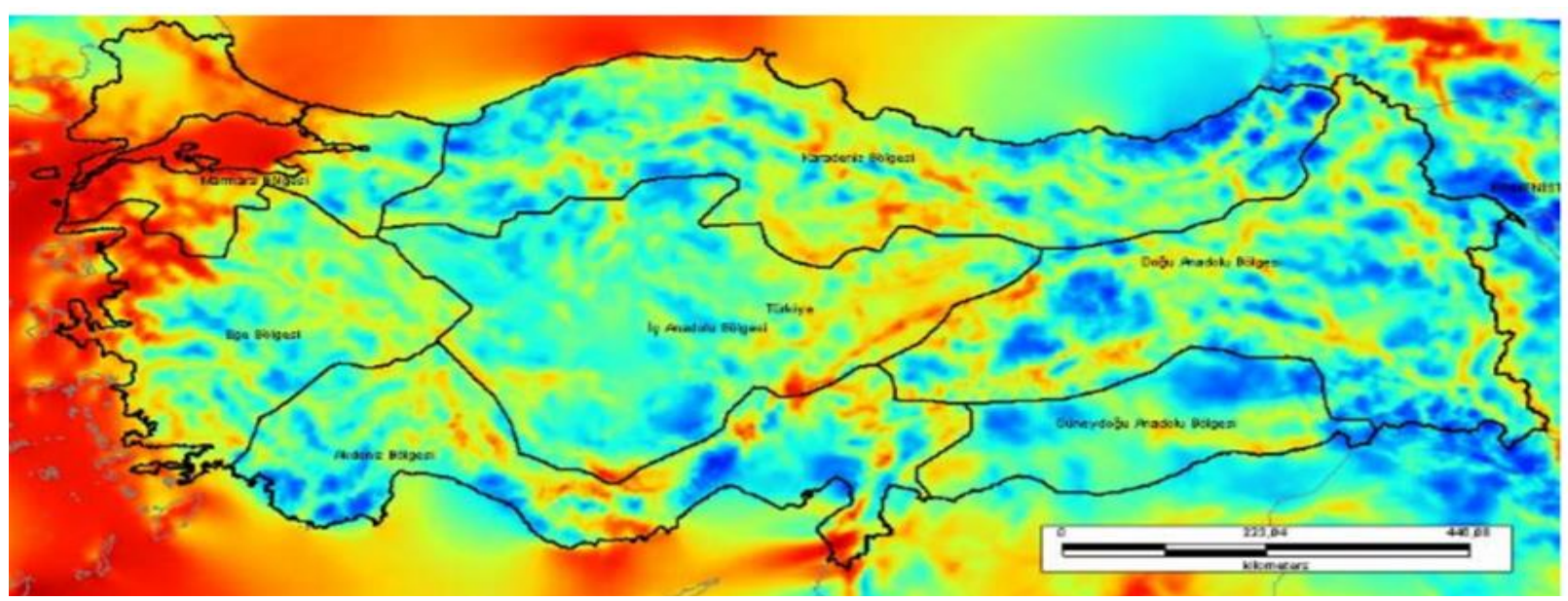

\section{KAPASITE} FAKTÖRÜ

(\%)

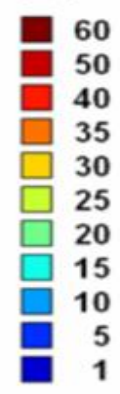

Şekil 5. Türkiye için 50 metre yükseklikte ortalama kapasite faktörü dağılımı

Türkiye'nin rüzgar enerji potansiyeli ortalama rüzgar hızı 7.0 $\mathrm{m} / \mathrm{s}$ 'den büyük değerler için Tablo 4'de görüldüğü gibidir (Çalışkan, 2019). Tablo incelendiğinde en yüksek kapasitenin $7.0-7.5 \mathrm{~m} / \mathrm{s}$ aralığında elde edildiği görülmektedir.

\section{Tablo 4. Türkiye'nin Rüzgar Enerjisi Potansiyeli (Ortalama} rüzgar hızl $>7,0 \mathrm{~m} / \mathrm{s}$ )

\begin{tabular}{|c|c|c|}
\hline $\begin{array}{l}\text { Yıllık Ortalama } \\
\text { Rüzgar Hızı - } 50 \text { m } \\
\text { (m/s) }\end{array}$ & $\begin{array}{l}\text { Güç Yoğunluğu - } \\
\quad 50 \mathrm{~m}\left(\mathbf{W} / \mathbf{m}^{2}\right)\end{array}$ & $\begin{array}{l}\text { Kapasite } \\
\text { (MW) }\end{array}$ \\
\hline $7.0-7.5$ & $400-500$ & $29.259,36$ \\
\hline $7.5-8.0$ & $500-600$ & $12.994,32$ \\
\hline $8.0-9.0$ & $600-800$ & 5399,92 \\
\hline \multirow[t]{2}{*}{$>9.0$} & $>800$ & 195,84 \\
\hline & Toplam & 47.849 \\
\hline
\end{tabular}

Türkiye rüzgar enerjisi potansiyelinden en yüksek derecede faydalanabilmek ve rüzgar santrallerinin sayılarının artırarak elektrik iletim/dağıtım sistemlerine bütünleşmesini sağlayabilmek hedefiyle TÜBITTAK Uzay Teknolojileri Araştırma Enstitüsü önderliğinde ve Meteoroloji Genel Müdürlüğü koordinatörlüğünde "Rüzgar Enerjisi İzleme ve Tahmin Merkezi Projesi” gerçekleştirilmektedir (Çalışkan, 2019). 20/10/2015 tarihli Rüzgar Kaynağına Dayalı Elektrik Üretimi Başvurularının Teknik Değerlendirmesi Hakkında Yönetmelik ile "Elektrik enerjisi üretiminde rüzgar enerjisinin verimli ve etkin kullanılmasını sağlamak, rüzgar kaynağına bağlı olarak yapılan önlisans veya lisanssız elektrik üretimi başvurularının teknik açıdan analizini yapmak, teknik analizlerin uygun bulunmuş olan önlisanslı, lisanslı veya lisanssız projelerin koordinat değişikliği, türbin teknik özellikleri ve kapasite artışları ile alakalı değişiklik istekleri hakkında uygunluk yazısının düzenlenmesine ilişkin usul ve esasları belirlemesine yönelik durumları hedeflemektedir" (Resmi Gazete, 2015).

Türkiye'de jeotermal potansiyelin en yüksek olduğu bölgeler; Ege, Marmara ve Anadolu'nun iç batı kısımında yer alan 
bölgelerdir. Arama ve keşif işlemleri hızla devam etmekte olup jeotermal enerji ve sondajlı araştırmaları derinliği $2000 \mathrm{~m}$ civarından $28000 \mathrm{~m}$ civarlarına geliştirilmiştir. 2005 senesinden günümüze Türkiye Cumhuriyeti Enerji ve Tabii Kaynaklar Bakanlığı yardımlarıyla, yeni kaynak bölgelerinin araştırılması ve eldeki kaynakların geliştirilmesi işlemlerinin üzerine ağırlık verilmesi sebebiyle, 2004 y1lı sonu itibari ile mevcut $3100 \mathrm{MWt}$ olan tüketilebilir 1sı kapasitesine sahiptir. 2008 yılında Jeotermal Kaynaklar ve Doğal Mineralli Sular Kanunu'nun yürürlüğe girmesinin yanı sıra jeotermal arama çalışmalarına özel sektörün de ağrılık vermesiyle yatırım ile geliştirme çalışmaları beraberinde Türkiye'nin toplamda jeotermal açıdan 1S1 kapasitesini (1s1 miktarının görünürlüğü) 35.500 MWt'e seviyelerine gelmiştir. Jeotermal 1sı potansiyeli Türkiye'nin muhtemel olarak $31.500 \mathrm{MWt}$ kapasiteye sahiptir. Elektik üretiminde kullanılan jeotermal enerji kaynaklarının Türkiye ölçeğinde mevcut kapasitesi 2000 MWe civarlarında olduğu öngörülmektedir (Türkiye Cumhuriyeti Enerji ve Tabii Kaynaklar Bakanlığı, 2021). Şekil 6'da Türkiye'deki jeotermal kaynakların haritası görülmektedir. Şekil 6 dikkatli incelendiğinde Ege bölgesinde jeotermal açıdan daha fazla yoğunluk olduğu görülmektedir.

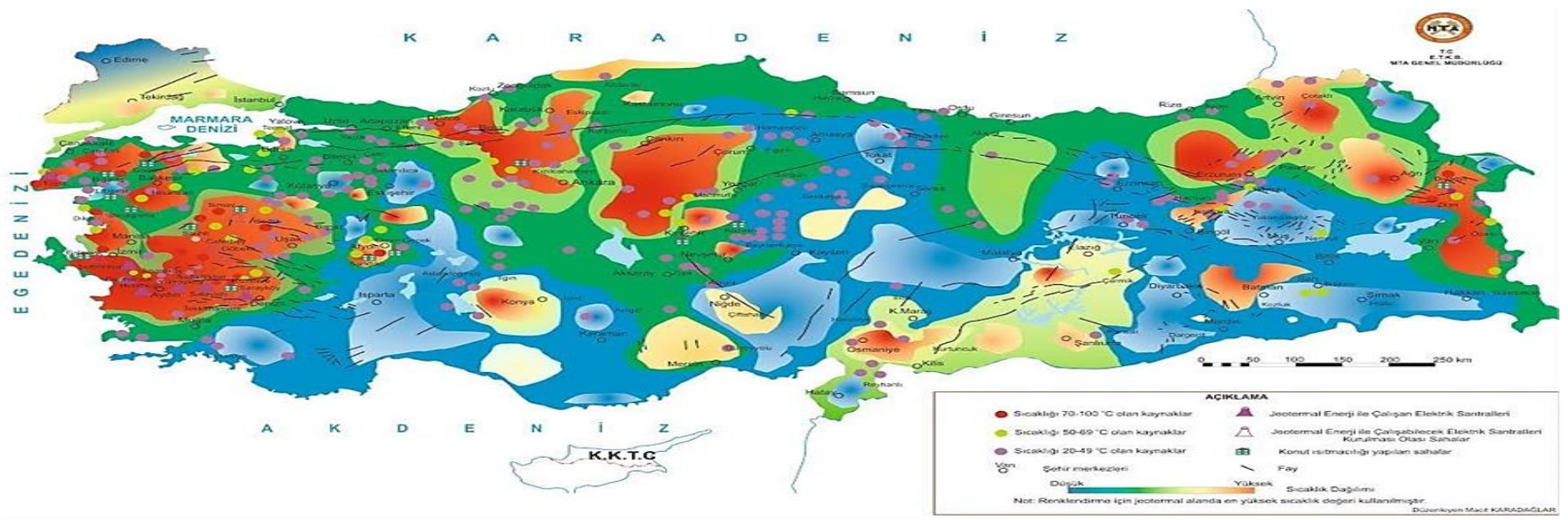

Şekil 6. Jeotermal kaynaklar ve uygulama haritası

2000'li yılların başından itibaren gelişen Türkiye'deki jeotermal çalışmalar, Tablo 5'de görülmektedir. 2002 yılında termal ve 1sıtma amaçlı kullanılan kapasite miktarı $675 \mathrm{MWt}$ seviyelerinden 2017 yılına gelindiğinde $2843 \mathrm{MWt}$ seviyelerine çıkarak artış göstermektedir. Elektrik üretimi adına 2002 yılında kullanımda olan kurulu güç 15 MWe'den, elektrik üretimin için uygun koşullara sahip jeotermal alanlarının tespit edilmesi, devlet ve özel işletmeler tarafından jeotermal enerji santrali yatırımları ile günümüzde $861 \mathrm{MWe}$ seviyelerine çıkmıştır (Zaim ve Çavşi, 2018).

Tablo 5. Türkiye'de ylllara göre jeotermal çalışmalar

\begin{tabular}{l|c|c|c}
\hline Kullanım Alanı & $\mathbf{2 0 0 2}$ & $\mathbf{2 0 1 3}$ & $\mathbf{2 0 1 7}$ \\
\hline Elektrik Üretimi & $15 \mathrm{MWe}$ & $311 \mathrm{MWe}$ & $861 \mathrm{MWe}$ \\
\hline Konut Isitması & $275 \mathrm{MWt}$ & $813 \mathrm{MWt}$ & $1033 \mathrm{MWt}$ \\
\hline Sera Isitması & $100 \mathrm{MWt}$ & $600 \mathrm{MWt}$ & $760 \mathrm{MWt}$ \\
\hline Termal Kullanım & $300 \mathrm{MWt}$ & $600 \mathrm{MWt}$ & $1050 \mathrm{MWt}$ \\
\hline
\end{tabular}

Biyokütle Enerjisi; Enerji için mevcut biyokütle, farklı nihai enerji türlerine dönüştürülebilir, örneğin 1s1 (odun kömürü ve üretici gaz) ve güç (elektrik) şeklinde dönüştürülebilir. Bunların arasında elektrik üretimi oldukça önemli bir yere sahiptir (Toklu,
2017). Biyokütle atık potansiyelinin Türkiye için yaklaşık olarak 8,6 MTEP ve üretimi yapilabilecek olan biyogaz rezervinin yaklaşık olarak 1,5-2 MTEP seviyelerinde olması öngörülmektedir (Türkiye Enerji ve Tabii Kaynaklar Bakanlığı, 2021). Biyokütle ürünleri üretimi açısından Türkiye, su kaynakları, tarımsal alanın kullanılabilirliği, iklim koşulları ve elverişli güneşe sahip olması nedeniyle biyokütle enerjisi açısından çok büyük bir hammaddeye sahiptir (İlleez, 2020). Türkiye'nin geneline bakıldığında biyokütle kaynakları orman, tarım, kentsel organik atık, hayvan vb. maddelerden meydana geldiğine dikkat edilecek olursa Türkiye'deki biyokütle enerjisi potansiyeli Şekil 7'deki haritada dağılımı görüldüğü gibi gerçekleşmektedir (Toklu, 2017). Şekil dikkatlice incelendiğinde Türkiye'nin neredeyse tamamı biyokütle enerjisinin elde edilebilmesi adına oldukça elverişlidir.

Enerji Tabii Kaynaklar Bakanlığı Yenilenebilir Enerji Genel Müdürlüğü'nün Biyokütle enerjisinin Türkiye'deki potansiyeli için hazırlamış olduğu Türkiye'nin Biyokütle Enerjisi Potansiyel Atlası (BEPA) isminde uygulama mevcuttur. BEPA vasitası ile Türkiye'nin herhangi bir bölgesinde biyokütle kaynak türlerinden hangilerinin biyoyakıt, hangilerinin elektrik üretme potansiyeli olduğu gözlemlenebilmektedir. Ayrıca mevcut kaynakların ülkenin hangi coğrafi bölgelerinde artış gösterdiğini harita üzerinde sayısal ifadeler ve grafiksel olarak canlı bir biçimde Coğrafik Bilgi Sistemi (CBS) uygulaması üzerinden erişime sunulmaktadır (İlleez, 2020). 


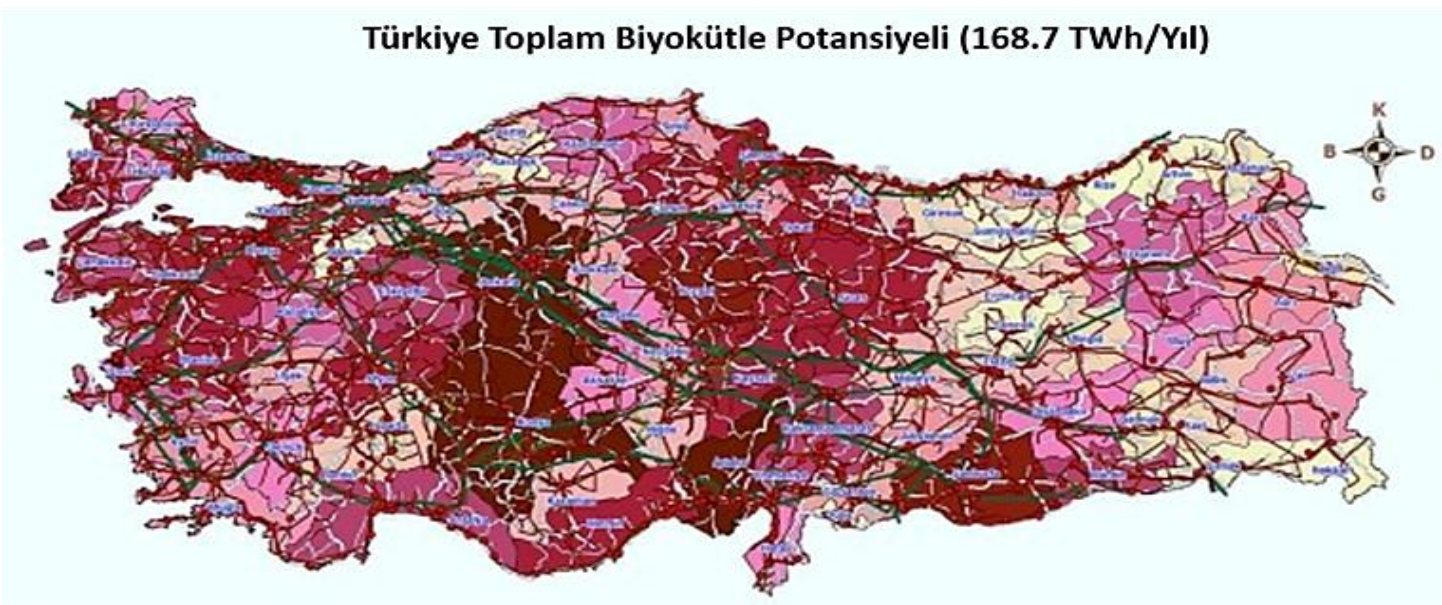

Şekil 7. Türkiye'de illere göre biyokütle potansiyel dă̆ılımı

Deniz kökenli enerji kaynağı olan gelgit enerjisi potansiyeli Türkiye'de çok azdır. Akıntı enerji kaynağı olarak ise Çanakkale ve İstanbul Boğazları uygun görünüyor olsada, deniz trafiğinin yoğunluğu sebebiyle kullanılması uygun olamamaktadır. Türkiye'de deniz kökenli enerji kaynaklarından bir diğeri olan dalga enerjisinden yararlanma imkânı bulunmaktadır. Türkiye'yi çevreleyen denizlerde yapılan ölçümler ile yıllık olarak 50 TWh'lik teknik potansiyel olduğu tespit edilmiştir. Marmara harici 2600 km'lik kıyı uzunluğu için 28 GW'lık dalga enerjisi potansiyeli tahmin edilmektedir (Adıyaman, 2012).

Türkiye'nin dalga potansiyeli açısından en yoğun bölgesi Ege ve Akdeniz bölgeleridir, Antalya-İzmir aralığında mevcut potansiyel en yüksek seviyelerdedir. Dalga enerjisinden elektrik üretimi yapılabilmesi adına İzmir(Finike-Dalaman) ve Antalya aralığ 1 en uygun yerler olarak öngörülmektedir (Sağlam ve Uyar, 2005).

Deniz enerjileri ile ilgili Türkiye'de ticari bir çalışma mevcut olmayıp yapılan çalışmaların çoğunluğu akademik olarak yapılmaktadır. Akademik çalışmalar kapsamında test amaçlı kurulan santraller mevcuttur. 2007 yılinda Enerji ve Tabii Kaynaklar Bakanlığınca yapılan bir proje sebebiyle uygulanmış bir sistem de mevcuttur. Uygulanan sistemde dalgaların düşey olarak hareketinin jeneratör vasitasıly elektrik enerjisine dönüştürüldüğü dubalar bulunmaktadır. Üretilen bu elektrik enerjisi yaklaşık olarak $5 \mathrm{kWh}$ gücünde ve iki eve yetebilecek seviyededir (Adiyaman, 2012).

Akarsuyun gücünden yararlanılarak hidroelektrik santrallerde üretilen enerji, yağış rejimine ve sıklığına göre farkl1lık göstermektedir. Mevsimlere ve bölgelere bağlı olarak Türkiye'de yağışlar ciddi bir biçimde farklılık göstermektedir. Türkiye'ye ortalama düşen $643 \mathrm{~mm}^{3} / \mathrm{y}$ ll yağış miktarı, yıllık olarak tahmini 501 milyar $\mathrm{m}^{3}$ su kütlesine eşdeğerdir. Türkiye coğrafyasına düşen yağış miktarının yaklaşık olarak \%50'ye yakını buharlaşma vasıtasıyla atmosfere karışmaktadır. \%35'lik kısmı ise dereler ve akarsular ile deniz veya göllere ulaşmaktadır. Geriye kalan yüzdelik kısım ise yerin altındaki su kaynaklarını besleme görevi üstlenmektedir. 21. Yüzyılın başlarındaki bir araştırmaya göre; Türkiye'de her bir bireye karşıllk gelen brüt su kütlesi yaklaşık olarak $3000 \mathrm{~m}^{3}$ olarak kayıtlara geçmiştir.
Uluslararası çalışmalarda ve kaynaklarda yer alan bilgiye göre bir bireyin kullanımına karşılık gelen su potansiyelinin miktarı 10000 $\mathrm{m}^{3} / \mathrm{y} \mathbf{l}^{\prime}$ dan çok olan ülkelere hidrolik potansiyel bakımdan varlıklı ülkeler denebilmektedir. 3000-10000 $\mathrm{m}^{3} / \mathrm{y} 1$ olan ülkeler ise kendi kendine yetebilen ülkeler sınıfina girmektedir. 1000-3000 m/3/yl seviyelerinde olan ülkeler ise su kıtllğı çekmektedir. $1000 \mathrm{~m}^{3} / \mathrm{yl}$ 'dan az suyu olan ülkelere ise fakir ülkeler olarak bakılmaktadır. Değerlendirmeler ve çalışmalar dikkate alındığında; sanılandan daha az su kaynağı bulunan Türkiye'nin su kaynağı bakımından su fakiri olan ülkeler arasında yer alma potansiyelinin yüksek olduğu görülmektedir. İklim değiş̧ikliği ve artan nüfus benzeri etkiler göz önüne alınırsa gelecekte su sıkıntısı çekecek ülkeler arasında Türkiye'de yerini alması muhtemeldir (Adıyaman, 2012). Türkiye hidroelektrik potansiyel haritası Şekil 8'de görüldüğü gibidir (Y1lmaz, 2018). Şekil 8'de Türkiye'deki hidroelektrik santral noktaları, akım gözlem istasyonları, akarsu ağları ve çeşitli göllerine yer verilmiş̧ir.

Türkiye'de yenilenebilir enerji kaynakları arasında önemli bir yeri ve potansiyeli olan birçok hidrolik enerji kaynağ mevcuttur. Teorik olarak hidroelektrik potansiyeli yaklaşı olarak 433 milyar kWh olmakla beraber teknik açıdan kullanılabilir potansiyeli 216 milyar $\mathrm{kWh}$ ve y1llı ekonomik getiriye bakıldığında 160 milyar $\mathrm{kWh}$ hidroelektrik enerji potansiyele sahiptir. Türkiye'de 2018 yılında 59,9 milyar kWh elektrik hidroelektrik kaynaklar ile üretilmiştir. 2019 yılı Ağustos ayı sonu itibari ile elektrik üretiminin hidrolik kaynaklardan elde edilmesi 68.452 GWh seviyelerine çıkmıştır. 2018 yılının yılsonu ile 28.291 MW'lık kurulu güce sahip aktif olarak işletmede bulunan 653 adet hidroelektrik santralin Türkiye'deki toplam kurulu gücünün \%31,9'una tekabül etmektedir. 2019 yılının Ağustos ayından bu yana Türkiye'de 28.437 MW hidroelektrik kurulu güç değerine çıkılmıştır (Türkiye Cumhuriyeti Enerji ve Tabii Kaynaklar Bakanlığı, 2021).

Türkiye'deki hidroelektrik santraller ile ilgili genel bilgiler Tablo 6 ve Tablo 7'de detaylı olarak görülmektedir. Tablolar incelendiğinde hidroelektrik tesisleri alanında devam eden çalışmalar mevcuttur. Hidroelektrik kurulu gücü gün geçtikçe artmaktadır. 


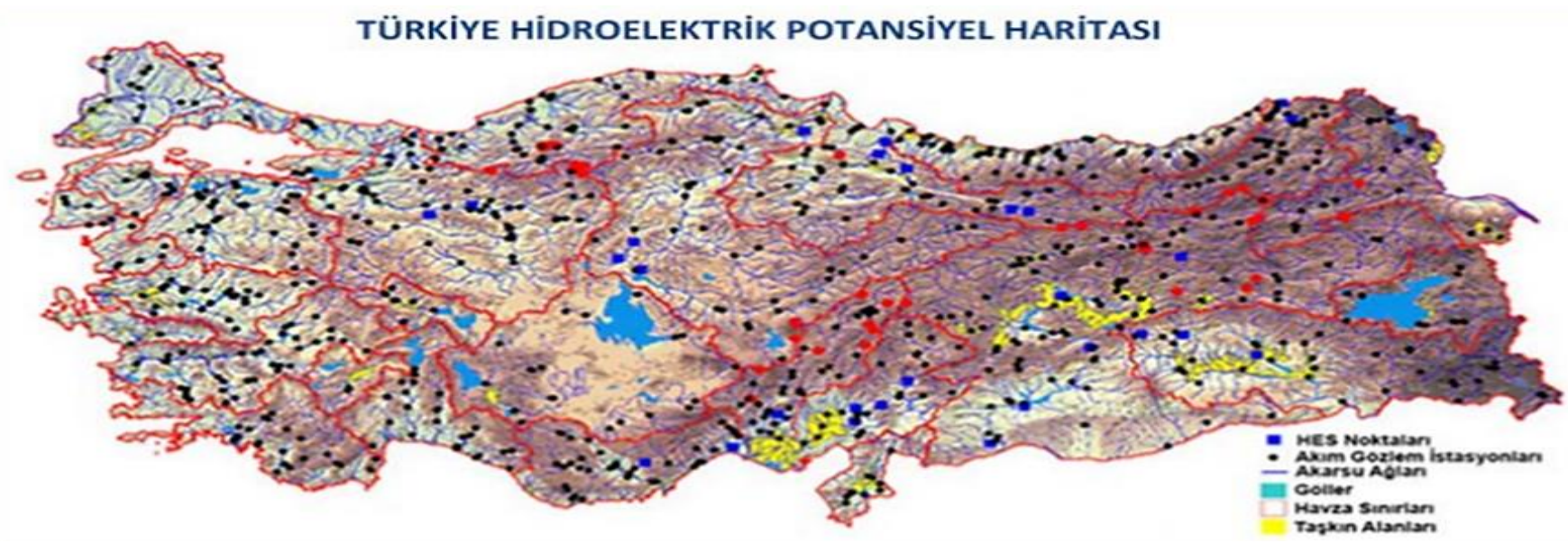

Şekil 8. Türkiye'nin hidroelektrik potansiyel haritası

Tablo 6. Hidroelektrik santralleri kurulu güç ve proje kapasiteleri

\begin{tabular}{l|c|c}
\hline Durum & Güç (MWe) & Oran \\
\hline Devrede & 31.325 & $\% 67,9$ \\
\hline Kurulumu devam eden & 2.684 & $\% 6,2$ \\
\hline Üretim lisansı alınan & 2.807 & $\% 6,4$ \\
\hline Önlisans alınan & 3.820 & $\% 8,8$ \\
\hline Proje aşamasında & 2.969 & $\% 6,8$ \\
\hline Toplam & 43.583 & $\% 100$ \\
\hline
\end{tabular}

Tablo 7. Hidroelektrik santral profili

\begin{tabular}{l|c}
\hline Kayıtlı Santral Sayısı & 679 \\
\hline Kurulu Güç & $31.325 \mathrm{Mwe}$ \\
\hline Kurulu Güce Oranı & $\% 32,29$ \\
\hline Yıllık Elektrik Üretimi & $80.015 \mathrm{GWh}$ \\
\hline Üretimin Tüketime Oranı & $\% 26,67$ \\
\hline
\end{tabular}

\section{Sonuçlar ve Değerlendirmeler}

Enerji, toplum olarak gelişmenin ve ekonomik anlamda kalkınabilmenin kaynağı olarak görülmektedir. İleriye yönelik ve doğru bir kalkınmada enerji, ülke ekonomisindeki büyümede ve toplumun refah seviyesinin artması adına önemli bir yer tutmaktadır. Her dönem için enerji ihtiyacı düşük maliyetli, güvenilir, sürdürülebilir ve aynı zamanda çevreye zararlı etkilerinin asgari seviyelere indirilmesi ana hedefler arasında yer alması zorunlu hale gelmiş bulunmaktadır. Türkiye'nin toplumsal refahı ve ekonomik kalkınması adına, enerji ihtiyacını dışarıya bağımlı kalmadan ve alternatif enerji kaynaklarını arttırmanın anahtarı, yıllardır göz ardı edilen öz kaynakların ve yenilenebilir enerji kaynaklarının geliştirilmesidir. Doğal potansiyelinin e-ISSN: 2148-2683 farkında olmayan ve bu potansiyellerini ilerletemeyen ülkeler, enerji talebini dışarıdan karşılamak zorunda kalacak ve bu durum ise ülke ekonomisine büyük zararlar verecektir.

Türkiye'ye ölçeğine bakıldığında önemli derecede enerji problemi mevcuttur. Doğal(Fosil) enerji kaynaklar açısından kaynaklarının yetersiz olduğu ve enerji ihtiyacının büyük bir kısmını başka ülkelerden ithal etmek durumunda olan bir ülke olan Türkiye, şayet yeni yapılacak olan yatırımları yerli ve yenilenebilir enerji kaynaklarını kullanımına yönelik tercih etmez ise enerji ihtiyacındaki dışa bağımlı olma durumu artacaktır. Bu dışa bağımlılığın oranı ise zamanla katlanarak artmaya devam edecektir. Bu süreçte dışa olan bağımlılık devam etmesi halinde ülke ekonomisi bakımından ve ayrıca arz güvenliği bakımından çok büyük problemlere neden olabilir. $\mathrm{Bu}$ duruma sebep olabilecek en büyük etken fosil yakıtlarıdır. Fosil yakıtların fiyatları her geçen sene artış göstermektedir.

Türkiye, yenilenebilir enerji kaynaklarının geliştirilmesi ve arttırılması konusuna son dönemde çok fazla önem vermektedir. 2017 yılında kabul edilen Milli Enerji Politikası çerçevesine uygun olarak yenilenebilir ve yerli enerji kaynaklarının yaygınlaştırılması ve aynı zamanda kullanımının artırılması temel hedefler arasında yerini almaktadır.

Türkiye'nin yenilenebilir ve yerli kaynakları elektrik enerjisinin üretimi konusunda ülke ihtiyaçlarına fazlasıyla yetebilecek seviyededir. Doğru ve etkin politikalar üzerine çalışmalar yapıldığında elektrik enerjisi üretiminin dışa olan bağımlılı̆̆ 1 ve bunun beraberinde getirdiği ekonomik yükümlülükler gelecek yıllarda azaltılabilir. Türkiye'de Tarım ve Kırsal Kalkınmayı Destekleme Kurumu ile Küçük ve Orta Ölçekli İşletmeleri Geliştirme ve Destekleme İdaresi Başkanlığı gibi kuruluşlar girişimcilere yenilenebilir enerji alanında maddi destekler verilmektedir. Gerek kamu bankaları gerekse özel bankalar yenilenebilir enerjinin potansiyeline maddi destek vermek adına geride kalmaktadır. Bu noktada özel girişimcilerin çeşitli bankalardan yenilenebilir enerji yatırımlarını yapabilmesi adına uygun faiz ve vadeler ile kredi imkânı elde edebilmesi adına yeni çalışmaların yapılması gerekmektedir. $\mathrm{Bu}$ gibi desteklerin arttırılarak yaygınlaşması sağlanmalı ve dişa bağımlılığın azaltılması hedeflenmelidir. Gelecek y1llar temiz, güvenilir ve yenilenebilir enerjinin daha çok tercih edildiği bir dönem olması Türkiye'nin ekonomik açıdan kalkınmasına büyük fayda sağlayacaktır. 


\section{Kaynakça}

Acaroğlu, M. (2003). Alternatif Enerji Kaynakları. İstanbul: Nobel Yayınevi.

Adryaman, Ç. (2012). Türkiye'nin Yenilenebilir Enerji Politikaları. Niğde: Niğde Üniversitesi Sosyal Bilimler Enstitüsü.

Atçı, M. E. (2012). Türkiye'nin Enerji Yatırımlarının Planlanması Sürecinin Bulanık Ahp Yöntemi ile Değerlendirilmesi. İstanbul: İstanbul Teknik Üniversitesi Fen Bilimleri Enstitüsü.

Atılgan, İ. (2000). Türkiye'nin Enerji Potansiyeline Bakış. Gazi Üniversitesi Mühendislik Mimarlık Fakültesi Dergisi, 15(1), 31-47.

Bektaş, A. (2013). Binalarda Rüzgar Enerjisi Kullanımının Farklı Bölgeler Açısından Değerlendirilmesine Yönelik Bir Çalışma: TOKİ Tarımköy Projesi Örneği. İstanbul: İstanbul Teknik Üniversitesi Fen Bilimleri Enstitüsü.

Çalışkan, M. (2019). Türkiye Rüzgar Enerjisi Potansiyeli. https://www.mgm.gov.tr/FILES/haberler/2010/retssemi ner/2_Mustafa_CALISKAN_RITM.pdf (Erişim tarihi 28.04.2021)

Gökkuş, G. (2014). Rüzgar Enerjisi Üretim Sistemlerinde İzleme ve Hata Kontrol Sistemleri. Ankara: Gazi Üniversitesi Fen Bilimleri Enstitüsü.

İlleez, B. (2020). Türkiye'de Biyokütle Enerjisi. Türkiye'nin Enerji Görünümü (pp. 317-346). Ankara: TMMOB Makina Mühendisleri Odas1.

Kadığlu, S., \& Tellioğlu, Z. (1996). Enerji Kaynaklarının Kullanımı ve Çevreye Etkileri. TMMOB 1. ENERJI SEMPOZYUMU. Ankara.

Koç, E., \& Şenel, M. C. (2013). Dünyada ve Türkiye'de Enerji Durumu-Genel Değerlendirme. Mühendis ve Makina Dergisi, 54(639), 32-44.

Kumbur, H., Özer, Z., Özsoy, D. H., \& Avc1, E. D. (2005). Türkiye'de Geleneksel ve Yenilenebilir Enerji Kaynaklarının Potansiyeli ve Çevresel Etkilerinin Karşılaştırılması. III. Yenilenebilir Enerji Kaynakları Sempozyumu ve Sergisi. Mersin.

Mert, S. (2012). Dalga Enerjisi Dönüşüm Sistemi Tasarımı Ve Deneysel Çalışması. İstanbul: İstanbul Teknik Üniversitesi Fen Bilimleri Enstitüsü.

Resmi Gazete. (2005). Yenilenebilir Enerji Kaynaklarının Elektrik Enerjisi Üretimi. (25819). https://www.resmigazete.gov.tr/eskiler/2005/05/200505 18-1.htm (Erişim tarihi: 24.05.2021).

Resmi Gazete. (2015). Rüzgar Kaynağına Dayalı Elektrik Üretimi Başvurularının Teknik Değerlendirmesi Hakkında Yönetmelik.https://www.resmigazete.gov.tr/eskiler/201 5/10/20151020-2.htm (Erişim tarihi: 21.05.2021).

Sağlam, M., \& Uyar, T. S. (2005). Dalga Enerjisi ve Türkiye'nin Dalga Enerjisi Teknik Potansiyeli. Yeksem, III.Yenilenebilir Enerji Kaynakları Sempozyumu. Mersin.

Tekno Tasarım. (2021). Hidroelektrik ve Enerji Türbinleri. https://www.erbakan.edu.tr/storage/files/department/ele ktrikelektronikmuhendisligi/Editor/DERS/YElkEnrUrt/ Hidroelektrik_Enerji_T\%C3\%BCrbinleri.pdf (Erişim tarihi: 17.05 .2021$)$

Toklu, E. (2017). Biomass energy potential and utilization in Turkey. Renewable Energy, 107, 235-244.
Türkiye Cumhuriyeti Dişişleri Bakanlığı. (2021). https://www.mfa.gov.tr/turkiye_nin-enerjistrateji.tr.mfa (Erişim tarihi: 30.04.2021)

Türkiye Cumhuriyeti Enerji ve Tabii Kaynaklar Bakanlığı. (2021). https://enerji.gov.tr/enerji (Erişim tarihi: 26.05.2021)

Türkiye Cumhuriyeti Enerji ve Tabii Kaynaklar Bakanlığı. (2021). https://enerji.gov.tr/bilgi-merkezi-enerji-petrol (Erişim tarihi: 22.04.2021).

Türkiye Cumhuriyeti Maden Teknik Arama Genel Müdürlüğü. (2020). Maden Teknik ve Arama Genel Müdürlüğü. https://www.mta.gov.tr/v3.0/arastirmalar/komur-aramaarastirmalari (Erişim tarihi: 22.04.2021).

Türkiye Cumhuriyeti Meteoroloji Genel Müdürlüğü. (2018). Türkiye Ortalama Güneşlenme Süresi (1988-2017). https://mgm.gov.tr/kurumici/turkiye-guneslenme suresi.aspx (Erişim tarihi: 24.05.2021)

Türkiye Doğalgaz Dağıtıcıları Birliği. (2016). Dünyada ve Türkiye'de Enerji Durumu. https:/www.gazbir.org.tr/ uploads/page/Dunya-ve Turkiye-Enerji-Gorunumu.pdf (Erişim tarihi: 22.04.2021).

Türkiye Elektrik İletim A.Ş. (2021). Santral Kurulu Güç Raporlar1. https://www.teias.gov.tr/tr-TR/kurulu-gucraporlari (Erişim tarihi: 23.04.2021).

Worldometer. (2020). https://www.worldometers.info/energy/ (Erişim tarihi:16.05 2021)

Yapar, M. (2014). Türkiye'de İktisat Politikaları Çerçevesinde Rüzgar Enerjisi Politikalarının Etkinliğinin Analizi: Bir Uygulama. İstanbul: İstanbul Üniversitesi Sosyal Bilimler Enstitüsü.

Yılmaz, M. (2012). Türkiye'nin Enerji Potansiyeli ve Yenilenebilir Enerji Kaynaklarının Elektrik Enerjisi Üretimi Açısından Önemi. Ankara Üniversitesi Çevrebilimleri Dergisi, 4(2), 33-54.

Yılmaz, Ş. (2018). Türkiye Hidroelektrik Potansiyeli ve Gelişme Durumu. Türkiye'nin Enerji Görünümü raporu 2018. 329-330

Zaim, A., \& Çavşi, H. (2018). Türkiye'deki Jeotermal Enerji Santrallerinin Durumu. Mühendis ve Makina Dergisi, 59(691), 45-58. 